\title{
Performance of different olive cultivars under time of grafting
}

\author{
Ibrar Hussain ${ }^{1 *}$, Nisar Naeem ${ }^{1}$, Ayub Jan ${ }^{1}$, Hafeez ur Rehman ${ }^{1}$, Ziaullah ${ }^{1}$ \\ and Saqib Ali ${ }^{2}$ \\ 1. Agriculture Research Institute Tarnab Peshawar-Pakistan \\ 2. The University of Agriculture Peshawar-Pakistan \\ *Corresponding author's email: ibrar_horti@yahoo.com \\ Citation \\ Ibrar Hussain, Nisar Naeem, Ayub Jan, Hafeez ur Rehman, Ziaullah and Saqib Ali. Performance of different olive \\ cultivars under time of grafting. Pure and Applied Biology. Vol. 5, Issue 4, pp1126-1130. \\ http://dx.doi.org/10.19045/bspab.2016.50135
}

\begin{tabular}{llll}
\hline \hline Received: 20/06/2016 & Revised: 10/10/2016 & Accepted: 15/10/2016 & Online First: 22/10/2016 \\
\hline
\end{tabular}

\section{Abstract}

The experiment "performance of different olive cultivars under time of grafting" was laid out in randomized complete block design with two factors factorial arrangement replicated three times. Three olive cultivars, i.e., Kalamata, Arbequina and FS-17 were used as scion on wild olive root stock with three different grafting times i.e. Early June, Mid July and late August. Different times of grafting significantly affected all of the parameters studied, except number of leaves. Significant differences were observed among cultivars for all variables studied, except for number of sprouts per grafting. In case of time of grafting, maximum sprouting percentage (73.8\%), number of sprouts (4.1), shoot length $(12.23 \mathrm{~cm})$, shoot diameter $(2.56 \mathrm{~mm})$, leaves per shoot (17.05) and minimum days to sprouting (26.6) were recorded in olive plants grafted in July. The plants grafted in June took higher days to sprout (32.7), minimum sprouting percentage $(67.7 \%)$ and shoot diameter $(1.97 \mathrm{~mm})$, whereas plants grafted in August attained minimum shoot length $(8.83 \mathrm{~cm})$. In case of performance of different cultivars, maximum sprouting percentage $(71.8 \%)$, shoot length $(11.48 \mathrm{~cm})$, Leaves per shoot $(17.43)$ and lower days to sprouting (28.5), and shoot diameter $(2.06 \mathrm{~mm})$ were attained by cultivars Arbequina, while Kalamata showed lower sprouting percentage (62.7\%), leaves per shoot (12.80) and maximum days to sprouting (30.1). It is concluded that July is the optimum time for grafting of olive cultivars, specifically Arbequina.

Keywords: Olive; Wild rootstock; Scion; Propagation; Grafting and timing

\section{Introduction}

Olea is one of the 30 genera belongs to family Oleaceae and the most famous specie of this genera is Olive (Olea europaea L.) with origin of Syria or Lebanon [1]. Olive is a widespread plant throughout the world, but remains a prevailing culture of Mediterranean Europe, with $98 \%$ of total world olive production [2].
Olive has high demand and is a need of modern day as oil crop. The modern horticulture is using new technologies and ideas to produce high quality fruits with minimum investment. The main objective of all nurserymen is to produce the quality plants, which enables the growers to plant what they are acquiring for high fruit production [3]. The success of vegetative propagation of fruit species depends on the 
genetic potential, physiological conditions of the mother plant, season of the year, hormonal balance, and environmental factors like temperature, light and humidity [4]. Grafting can be a desirable method to propagate plants which are hard to root [5]. Grafting is a common and successful technique used in many woody plants having same species and help the plants to assist scion in sharing water and nutrients via roots and easy adaptation to the environment [6]. Plants propagated through grafting ensure same qualities of mother plant, which is of prime importance to have an orchard with plants of known capacity [7]. Olive having a lot of problems by propagation through other means like seed, the daughter plants are not true to type, there fruit quality is much inferior and of no use, while propagation through cutting there is $30-50 \%$ under much control condition in few cultivars [8]. The development of this technique for olive tree varieties selected clonally will allow to develop technology also for other the fruit trees like analyzing the rootstock- scion influence on the biological characteristics of the resulting plant development, vigor, productivity, quality of the fruit and oil production. It will also help to find out the incompatibilities between the possible rootstock-scion combinations, to quantify the quality of the grafting, to study the possible transfer of characters, and even to improve the tolerance of the resulting plant to adverse conditions of soil, climate and parasites.

keeping in view these future prospects of Olive and the problems that growers are facing with producing true to type olive plants of different varieties, the present research was initiated to study the impact of time of grafting on different olive cultivars.

\section{Materials and methods}

The experiment was conducted at Agricultural Research Institute Tarnab Peshawar, Pakistan during 2014 under the project "Research, development and Promotion of Olive in Khyber Pakhutnkhwa, Pakistan". The experiment was laid out in randomized complete block design with two factors factorial arrangement replicated three times. Three olive cultivars, i.e., Kalamata, Arbequina and FS-17 were used as scion on wild olive root stock with three different grafting times i.e. Early June, Mid July and late August. 10 plants were use per plot. The experiment was conducted in lath house having 50\% shade. All the cultural practices were kept constant for all the treatment. The monthly average temperature $\left({ }^{\circ} \mathrm{C}\right)$, average relative humidity $(\%)$, rainfall and solar radiation recorded during the trials are presented in Table 1.

During the experiment, the nursery plants were evaluated on the basis of days to sprouting by counting the days from date of grafting plants until it starts sprouting, sprouting percentage by measuring number of plants sprouted per treatment and then percentage was calculated, shoot length through measuring tape, shoot diameter was measured through digital vernier caliper and number of leaves by counting leaves on each shoot and then average was calculated. All the recorded data was statistically analyzed using analysis of variance (ANOVA) and the means were compared using LSD test, when the F-values were significant [9]. The data were analyzed using statistical software MSTATC (Michigan State University).

\section{Results and discussion}

\section{Days to sprouting}

The variable days to sprouting was significantly affected by different time of grafting and different cultivars, while the interaction of varieties and time of grafting showed non-significant results. Maximum days to sprouting (32.7) were observed in plants grafted in June and minimum days to sprouting (26.6) were recorded in month of July. The quick sprouting in July may be due to high humidity and optimum 
temperature in July [10]. Hussain et al., [11] also found July as best time for grafting in shade house conditions in monsoon subtropical areas due to high humidity and rainfall creates optimum conditions for graft success (Table 1). In case of the response of different cultivars, FS-17 took maximum days to sprouting (31), while minimum were recorded in Arbequina (28.5). The less days to sprouting in Arbequina is due to the early new wound-repair xylem which is influenced by the activities of the scion rather than the rootstock [5]. Stoddard and McCully, [12] found that leaves and buds near the graft union are an important source of xylem-inducing stimuli, and an auxin gradient is necessary for vascular tissue regeneration.

Table 1. The monthly average of temperature $\left({ }^{\circ} \mathrm{C}\right)$ and average relative humidity $(\%)$, rainfall $(\mathrm{mm})$ and solar radiation $\left(\mathrm{Cal} / \mathrm{cm}^{2} / \mathrm{day}\right)$ recorded during the trials are presented

\begin{tabular}{|c|l|c|c|c|c|}
\hline \multicolumn{2}{|c|}{ Climate variables } & $\begin{array}{c}\text { Temperature } \\
(\mathbf{0})\end{array}$ & $\begin{array}{c}\text { Relative Humidity } \\
(\mathbf{\%})\end{array}$ & $\begin{array}{c}\text { Rainfall } \\
(\mathbf{m m})\end{array}$ & $\begin{array}{c}\text { Solar radiation } \\
\left(\mathbf{C a l} / \mathbf{c m}^{2} / \mathbf{d a y}\right)\end{array}$ \\
\hline \multirow{6}{*}{ Months } & June & 31.1 & 53.0 & 10.0 & 309 \\
\cline { 2 - 6 } & July & 31.8 & 66.5 & 317.2 & 229 \\
\cline { 2 - 6 } & August & 30.0 & 72.5 & 103.8 & 189 \\
\cline { 2 - 6 } & September & 27.4 & 70.1 & 9.0 & 232 \\
\cline { 2 - 6 } & October & 24.3 & 70.3 & 0 & 243 \\
\cline { 2 - 6 } & November & 17.4 & 55.2 & 0 & 230 \\
\hline
\end{tabular}

\section{Sprouting percentage}

This variable was significantly affected by time of grafting and cultivars used, while the interaction was non-significant (Table 2). The plants grafted in July showed maximum sprouting percentage $(73.8 \%)$ and minimum was recorded in the month of June $(67.7 \%)$. The results are in accordance with [13] which states that seasonal variation in graft take appears to be related to quantitative changes in the supply of materials (carbohydrate) available in the scion for forming the graft union. Similarly, the maximum sprouting percentage was recorded in Arbequina ( $71.8 \%$ ), followed by FS-17 (68.1\%), and the minimum was recorded in Kalamata $(62.7 \%)$. The Arbequina olive may have good response because of developing vascular tissue in a graft union region, which ensures transport of water, nutrients, plant hormones and phyto assimilates [14]. These findings are in accordance with [15] who state that grafting success varies by changing both the time of grafting and cultivars.

\section{Number of sprouts per plant}

The number of sprouts per plant were significantly affected by time of grafting, while different cultivars and the interaction in both was non-significant. In case of time of grafting, maximum (4.1) number of sprouts was observed in nursery plants grafted in July, while the one grafted in August show minimum (3.1) sprouts per plant. Among the performance of different cultivars, Arbequina and FS-17 showed highest number of sprouts (3.47), while Kalamata recorded lower number of sprouts per plant (3.41). The results are in accordance with [15] who state that two cultivars of same genetic background show differences in growth and development due to alterations in transport of water and nutrients and even the transport of some hormones.

\section{Shoot length}

Sprouts length was significantly affected by time of grafting and different olive cultivars (Table 2) used, while the interaction of both had non-significant effect on the sprouts 
length. Maximum shoot length $(12.23 \mathrm{~cm})$ was obtained by nursery plants grafted in July, while grafting in August had minimum sprouts length $(8.83 \mathrm{~cm})$. In case of different cultivars, Arbequina showed higher sprouts length $(11.48 \mathrm{~cm})$ followed by FS-17 (10.66 $\mathrm{cm})$ and Kalamata $(8.43 \mathrm{~cm})$. The results are in agreement with the findings of [13], who state that different scion have different shoot length with same root stock. They also have different shoot length with different time of grafting.

Table 2. Days to sprouting, sprouting percentage, Number of sprouts per plant, Number of leaves per shoot, shoot diameter and shoot length as affected by different time of grafting on different cultivars

\begin{tabular}{|l|l|l|l|l|l|l|}
\hline Variables & $\begin{array}{l}\text { Days to } \\
\text { sprouting }\end{array}$ & $\begin{array}{l}\text { Sprouting } \\
\text { percentage } \\
(\boldsymbol{\%})\end{array}$ & $\begin{array}{l}\text { Number } \\
\text { of sprouts }\end{array}$ & $\begin{array}{l}\text { Leaves } \\
\text { per shoot }\end{array}$ & $\begin{array}{l}\text { Shoot } \\
\text { diameter } \\
(\mathbf{m m})\end{array}$ & $\begin{array}{l}\text { Shoot } \\
\text { Length } \\
(\mathbf{c m})\end{array}$ \\
\hline TIMING (T) & & & & & & \\
\hline June & $32.7 \mathrm{~A}$ & $67.7 \mathrm{~B}$ & $3.1 \mathrm{~B}$ & $14.05 \mathrm{~A}$ & $1.97 \mathrm{~B}$ & $9.50 \mathrm{~B}$ \\
\hline July & $26.6 \mathrm{C}$ & $73.8 \mathrm{~A}$ & $4.1 \mathrm{~A}$ & $17.05 \mathrm{~A}$ & $2.56 \mathrm{~A}$ & $12.23 \mathrm{~A}$ \\
\hline August & $30.2 \mathrm{~B}$ & $67.7 \mathrm{~B}$ & $3.1 \mathrm{~B}$ & $13.86 \mathrm{~A}$ & $2.19 \mathrm{AB}$ & $8.83 \mathrm{~B}$ \\
\hline Significance & $*$ & $*$ & $*$ & $\mathrm{~ns}$ & $*$ & $*$ \\
\hline LSD & 2.092 & 5.384 & 0.759 & 3.346 & 0.430 & 0.773 \\
\hline CULTIVARS(C) & & & & & & \\
\hline Kalamata & $30.1 \mathrm{AB}$ & $62.7 \mathrm{~B}$ & $3.41 \mathrm{~A}$ & $12.81 \mathrm{~B}$ & $2.54 \mathrm{~A}$ & $8.43 \mathrm{C}$ \\
\hline Arbequina & $28.5 \mathrm{~B}$ & $71.8 \mathrm{~A}$ & $3.47 \mathrm{~A}$ & $17.44 \mathrm{~A}$ & $2.06 \mathrm{~B}$ & $11.48 \mathrm{~A}$ \\
\hline FS-17 & $31.0 \mathrm{~A}$ & $68.1 \mathrm{AB}$ & $3.47 \mathrm{~A}$ & $14.72 \mathrm{AB}$ & $2.11 \mathrm{~B}$ & $10.66 \mathrm{~B}$ \\
\hline Significance & $*$ & $*$ & $\mathrm{~ns}$ & $*$ & $*$ & $*$ \\
\hline LSD & 1.941 & 6.285 & 0.577 & 2.757 & 0.272 & 0.525 \\
\hline Interaction & & & & & & \\
\hline T x C & $\mathrm{ns}$ & $\mathrm{ns}$ & $\mathrm{ns}$ & $\mathrm{ns}$ & $\mathrm{ns}$ & $\mathrm{ns}$ \\
\hline
\end{tabular}

Means followed by the same letter are non-significant at 5\% level of significance, using LSD test at 5\% level of significance.

\section{Shoot diameter}

Time of grafting and olive cultivars had a significant response to shoot diameter. Maximum shoot diameter $(2.56 \mathrm{~mm})$ was observed in July followed by August (2.19 $\mathrm{mm}$ ), while nursery plants grafted in June had lower shoot diameter (1.97 mm). Among different cultivars studied, Kalamata had higher shoot diameter $(2.54 \mathrm{~mm})$ followed by FS-17 (2.11 mm) while Arbequina attained lowest shoot diameter $(2.06 \mathrm{~mm})$. The higher shoot diameter in Kalamata may be due to growth regulator and auxin, which is transported at different rates between grafts on different rootstocks, affects cytokinin production in roots and causes differences in shoot growth $[16,17]$.
As the shoot length is higher in Arbequina which causes the diameter of shoot to remain lower.

\section{Leaves per shoot}

This variable was significantly affected by times of grafting, while olive cultivars had non-significant effect on leaves per shoot. Olive nursery plants grafted in July attained higher number of leaves (17.05), while plants grafted in August showed lower number of leaves (13.86). The higher number of leaves in July is due to more number of sprouts and higher shoot length. Arbequina produced more number of leaves (17.44), followed by FS-17 (14.72) and Kalmata (12.81). The higher leaves in Arbequina is due to higher shoot length 
which support more number of leaves than other olive cultivars studied. The results are in line with [18] who stated that higher xylem to phloem directly affect transport of nutrients and have additive impact on the plant growth.

\section{Conclusion}

Olive cultivars grafted in July showed better performance for days to sprouting, sprouting percentage, number of sprouts, shoot length and shoot diameter. Hence new Olive plants can be successfully produced on wild olives through grafting with higher success when grafted in the month of July.

\section{Authors' contributions}

Conceived and designed the experiments: I Hussain, Performed the experiments: I Hussain, N Naeem \& S Ali, Analyzed the data: A Jan \& H Rehman, Contributed reagents/ materials/ analysis tools: Ziaullah \& H Rehman, wrote the paper: I Hussain \& S Ali.

\section{References}

1. Daniel LM, Adelson FO \& Hugo AM (2006). Azeitona e azeite de oliva: Informe Agropecuário, Belo Horizonte 27: 231.

2. Torres L (2007). Manual de Protecção Integrada do Olival. João Azevedo Editor. Viseu.

3. Fachinello JC (2005). Propagation of fruit plants. Brazil: Embrapa Informações Tecnológicas 221p.

4. Soundy P, Mpati KW, Dutoit ES, Mudau FN \& Araya HT (2008). Influence of cutting position, medium, hormone and season on rooting of fever tea (Lippia javanica L.) stem cuttings. Med Aromat Plant Sci Biotechnol 2(2): 114-116.

5. Hartmann HT, Kester DE, Davies FT \& Geneve RL (1997). Plant propagation principles and practices. 6th ed. Prentice Hall, Englewood Cliffs, N.J.

6. Loehle C \& Jones R (1990). Adaptive significance of root grafting in trees. Functional Ecol 4(2): 268-271.

7. Pinto ACQ, Borges AL, Magalhães AFJ, Nascimento AS, Matos AP, Almeida CO, Coelho EF, Cunha GAP, Filho HPS, Souza JS, Sampaio JMM, Mendes LN, Castro
NMT, Pereira RJ \& Carvalho RS (2000). Mango/ Techincal aspects of production. Brasília-DF. Embrapa. 63p.

8. Awan AA, Iqbal A, ur Rehman MJ \& Idris G (2003). Response of olive hard wood cuttings to different growth media and basal injuries for propagation. Asian Journal of Plant Sciences 2(12): 883-886.

9. Jan MT, Shah P, Hollington PA, Khan MJ \& Sohail Q (2009). Agriculture Research: Design and Analysis, a Monograph. Agric. Univ. Peshawar, Pakistan.

10. Elgimabi MENE (2009). Improvement of propagation by hardwood cuttings with or without using plastic tunnel in Hamelia patens. World J. Agric. Sci 5(5): 522-524.

11. Hussain I, Awan AA, Ali S, Jan I, Khan MA, Khan AA \& Karim W (2016). Effect of Grafting Time and Cultivar on Successful Propagation of Italian Olive in Hot Summer of Peshawar-Pakistan. AmEuras. J. Agric. \& Environ. Sci 16 (2): 289293.

12. Stoddard FL \& McCully ME (1980). Effects of excision of stock and scion organs on the formation of the graft union in coleus: a histological study. Bot. Gaz. 141:401-412.

13. Flavio Z, Liege DSO \& Luiz AB (2011). Grafting of Araucaria angustifolia (bertol.) kuntze through the four seasons of the year. Rev. Bras. Frutic 33(4):1364-1370.

14. Julia AD, Yulia VS, Eugene AV, Alexi MG \& Galina VK (2011). Grafts of woody plants and the problem of incompatibility between scion and rootstock (a review) $\mathrm{J}$ Siberian Federal Uni Biology 1(4): 54-63.

15. Simone AZS, Idemir C \& Moeses AD (2010). Propagation of Brasilian grapes through grafting and layering. Rev. Bras. Frutic 32(2): 571-576.

16. Lockhard RG \& Schneider GW (1981). Stock and scion growth relationships and the dwarfing mechanisms in apple. Hort. Rev 3: 315-375.

17. Webster AD (1998). Strategies for controlling the size of sweet cherry trees. Acta Hortic 468: 229-239.

18. Soumlidou K, Battey, NH, Barnet JR \& John P (1994). The anatomy of developing bud union and it,s relation to dwarfing in Apple. Ann. Bot 74: 605-611. 